\title{
Innovation systems: from fixing market failures to creating markets*
}

Mariana Mazzucato

University of Sussex Brighton

\section{Innovation systems: from fixing market failures to creating markets}

This paper presents a critique of the market failure theory, focusing on its limitations for explaining the creation of new markets. From a review of the literature on the subject and several examples, I argue that the state has an essential role in fostering innovation. Therefore, the challenges for innovation in the future should be less focused on the worries about 'picking winners' and 'crowding out'. Instead, we must open up the discussion towards four key questions: 1) directions; 2) evaluation; 3) organisational change; 4) risks and rewards.

Keywords: market, innovation, economy, efficiency, trade policy, intervention

\section{Sistemas de inovação: da regulação das falhas de mercado à criação de novos mercados}

Este trabalho apresenta uma crítica à teoria das falhas de mercado, com foco em suas limitações para explicar a criação de novos mercados. A partir de uma revisão da literatura sobre o tema e de diversos exemplos, o artigo defende que o Estado tem um papel essencial na promoção da inovação. Portanto, os desafios para a inovação no futuro devem ser menos focados nas preocupações com "escolha de vencedores" e "crowding out". Em vez disso, é necessário focar em quatro questões-chave : 1) as direções; 2) avaliação; 3) mudança organizacional ; 4) riscos e recompensas.

Palavras-chave: mercado, inovação, economia, eficiência, política comercial, intervenção

\footnotetext{
* Este artigo convidado foi apresentado no Seminário Internacional "Papel do Estado no Século XXI: desafios para a Gestão Pública", organizado pela Escola Nacional de Administração Pública e pelo Ministério do Planejamento, Orçamento e Gestão e sediado em Brasília nos dias 3 e 4 de setembro de 2015.
} 
Sistemas de innovación: de la regulación de los fallos de mercado a la creación de nuevos mercados

Este trabajo presenta una crítica a la teoría de los fallos de mercado, con enfoque en sus limitaciones para explicar la creación de nuevos mercados. A partir de una revisión de la literatura acerca del tema y de varios ejemplos, el artículo defiende que el Estado tiene un papel esencial en la promoción de la innovación. Por lo tanto, los retos a la innovación en el futuro deben estar menos enfocados en las preocupaciones con la "elección de vencedores" $\mathrm{y}$ "desplazamiento" (crowding out). En vez de eso, es necesario enfocar cuatro cuestiones clave: 1) las direcciones; 2) evaluación; 3) cambio organizacional; 4) riesgos y recompensas.

Palabras clave: mercado, innovación, economía, política comercial, intervención 
The important thing for Government is not to do things which individuals are doing already, and to do them a little better or a little worse; but to do those things which at present are not done at all.

John M. Keynes, The End of Laissez Faire, 1926

The road to the free market was opened and kept open by an enormous increase in continuous, centrally organized and controlled interventionism.

Karl Polanyi, The Great Transformation, 1944

Instead of asking: what benefits [has] this project yielded, it would almost be more pertinent to ask: how many conflicts has it brought in its wake? How many crises has it occasioned and passed through? And these conflicts and crises should appear both on the benefit and the cost side, or sometimes on one -sometimes on the other, depending on the outcome (which cannot be known with precision for a long time, if ever).

Alfred O. Hirschman ${ }^{1}$

\section{Beyond market failure}

Today countries around the world are seeking 'smart' innovation led growth. And hoping that this growth is also more 'inclusive' and 'sustainable' than in the past (European Commission, 2010). Such a feat requires rethinking the role of government and public policy in the economy-funding not only the 'rate' of innovation, but also envisioning its 'direction'. It requires a new justification of government intervention that goes beyond the usual one of 'fixing market failures'. It requires shaping and creating of markets. And to render such growth more 'inclusive' it requires attention to the ensuing distribution of 'risks and rewards'.

Complexity theory is relevant here because innovation is (1) a collective process, defined by a system of heterogeneous public and private actors, interacting in different ways; (2) it is a fundamentally uncertain process (in the knightian sense) with most attempts ending in failure; and (3) it is a path-dependent, cumulative and highly clustered (wave-like) process, characterised by fat tailed distributions. Unfortunately models of innovation continue to pretend the opposite, i.e that (1) it is driven mainly by individual genius of 'entrepreneurs', at best 'facilitated' by the public sector; (2) only characterised by 'risk' (see the 'lottery' models of endogenous growth theory); and (3) can be modelled as a 'random walk' (with little

\footnotetext{
${ }^{1}$ Cited in Adelman, J. (2013). Worldly philosopher: the odyssey of Albert O. Hirschman. Princeton: Princeton University Press, p. 313.
} 
persistence) that statistically appears as a Gaussian process. Understanding the collective, uncertain and persistent nature of innovation helps us to understand the kind of policy questions that we should be asking if we want to achieve smart innovation led growth.

Market failure theory justifies public intervention in the economy only if it is geared towards fixing situations in which markets fail to efficiently allocate resources (ARROW, 1951). The market failure approach suggests that governments intervene to 'fix' markets by investing in areas with 'public goods' characteristics (such as basic research, or drugs with little market potential) and by devising market mechanisms to internalise external costs (such as pollution) or external benefits (such as herd immunity). Five key sources of market failures - that is, factors or behaviours that result in costs or benefits that are not reflected in the price system - include imperfect competition, information failures, negative externalities, public goods and coordination failures (MAZZUCATO; PENNA, 2014).

Within the mainstream framework, market failure is a necessary but not sufficient condition for governmental intervention (WoLF, 1988). The sufficiency results from an assessment that the gains from the intervention outweigh the associated costs due to 'governmental failures' (TULLOCK et al., 2002) - such as capture by private interests (nepotism, cronyism, corruption, rent-seeking) (KRUEGER, 1974), misallocation of resources (for example, 'picking losers') (FALCK et al., 2011), or undue competition with private initiatives ('crowding out') (FRIEDMAN, 1979). Thus, there is a trade-off between two inefficient outcomes; one is generated by free markets (market failure) and the other by governmental intervention (government failure). The solutions advocated by Neo-Keynesians focus on correcting failures such as imperfect information (STIGLITZ; WEISS, 1981). Solutions advocated by public choice scholars (BUCHANAN, 2003) focus on leaving resource allocation to markets (which may be able to correct their failures on their own). While market failure theory provides interesting insights, it is at best useful for describing a steady state scenario in which public policy aims to put patches on existing trajectories provided by markets. It is less useful when policy is needed to dynamically create and shape new markets, as in the cases of the Internet, nanotech, biotech, cleantech. There are four key limitations in Market failure theory.

1. Directionality: envisioning and 'picking'strategically. Policies that aim to correct markets assume that once the sources of the failure have been addressed, market forces will efficiently direct the economy to a path of growth and development. Yet, markets are 'blind' (NELSON; WINTER, 1982; DosI, 1982) and the direction of change provided by markets often represents suboptimal outcomes from a societal point of view. This is why, in addressing societal challenges, states have had to lead 
the process and provide the direction towards new 'techno-economic paradigms' (PEREZ, 2002), which do not come about spontaneously out of market forces. In the mass production revolution and the IT revolution, governments made direct 'mission-oriented' investments in the technologies that enabled these revolutions to emerge, and formulated bold policies that allowed them to be fully deployed throughout the economy (MOWERY, 2010; BLOCK; KELLER, 2011). As I show in my recent book (MAZZUCATO, 2013a), every technology that makes the iPhone 'smart' (Internet, GPS, touch-screen display, and SIRI) was publicly funded directly. And even the deployment of most 'general purpose technologies' (from electricity to IT) was an outcome of public policy (PEREZ, 2002). Furthermore, in the IT revolution, and even in the emerging clean-tech revolution, government not only funded the actual technologies (such as mainframes, the Internet, wind and solar power, and fuel cells), but also created a network of decentralized public and private actors (a 'developmental network state') (BLOCK; KELLER, 2011), provided early-stage funding to companies that risk-averse private finance would not, and devised special tax credits that favoured some activities more than others (MAZZUCATO, 2013a, 2013b). These facts seem to point to a different analytical problem facing policy makers: not whether the right role is that to intervene or stand back, but understanding how particular 'directions' and routes can be chosen, and determining how to mobilise and manage activities that can lead to the achievement of dynamic social and technological challenges.

2. Evaluation: static vs. dynamic metrics. Market failure theory has developed concrete indicators and methods to evaluate government investments, usually through a cost-benefit analysis that estimates whether the benefits of public intervention compensate for the costs associated both with the market failure and the implementation of the policy (including 'governmental failures'). However, there is a mismatch between the intrinsically dynamic character of economic development and the static tools used to evaluate policy. The diagnostic tools and evaluation approach based on Market failure theory involves identifying the sources of market failure and targeting policy interventions on their correction. This entails ex-ante considerations about administrative and fiscal requirements and the political-economic consequences of intervention.

Yet this is a limited toolbox, because it represents a static evaluation of an intrinsically dynamic process. By not allowing for the possibility that government can transform and create new landscapes that did not exist before, the ability to measure such impact has been affected (MAZzUCATO, 2013a). This then leads to accusations of government 'crowding out' businesses. However, the goal of public investments should be to not only 'kickstart' the economy but to choose directions that "do those things which at present are not done at all" (KEYNES, 1926). We need 
indicators for such transformative action, in order to avoid investments that are too narrow or directed within the confines of the boundaries set by business practices of the prevailing techno-economic paradigm (ABRAHAM, 2010).

3. Organisation: learning, experimentation and self-discovery. Market failure theory calls for the state to intervene as little as possible in the economy. This view requires has resulted in a trend of 'outsourcing' that often rids government of the knowledge capabilities (for example, around IT) that are necessary for managing change. Studies have examined the influence of outsourcing on the ability of public institutions to attract top-level talent with the relevant knowledge and skills to manage transformative mission-oriented policies (KAKABADSE; KAKABADSE, 2002). Indeed, there seems to be a self-fulfilling prophecy whereby the less 'big thinking' occurs in government, the less talent/expertise the public sector is able to attract, the less well it performs, the less 'big thinking' it is allowed to do. In order to promote transformation of the economy, by shaping and creating technologies, sectors and markets, the state must organise itself so that it has the 'intelligence' (policy capacity) to think big and formulate bold policies. This does not mean it will always succeed, indeed the underlying uncertainty in the innovation process means that the state will often fail (NELSON; WINTER, 1982; HIRSCHMAN, 1967). If the emphasis is on the process of policy making (RODRIK, 2013) that can allow the public sector to envision and manage transformational change, then understanding the appropriate structures of public organisations and their 'absorptive capacity (COHEN; LeVINTHAL, 1990) is essential.

4. Risks and Rewards: towards symbiotic private-public partnerships. Market failure theory says little about cases in which the state is the lead investor and risk taker in capitalist economies through 'mission-oriented' investments and policies (ForAy et al., 2012). Having a vision of which way to drive an economy requires direct and indirect investment in particular areas, not just 'creating the conditions' for change. This requires crucial choices to be made, the fruits of which will create some winners, but also many losers. Figure 1 below shows how much public money has been spent on early stage seed financing through the US Small Business Innovation Research programme. Indeed, precisely because venture capital has become increasingly short-termist, with emphasis on an exit in 3 years (while innovation takes 15-20 years!), such funding has become increasingly important. As have also guaranteed loans for innovative high risk projects. For example, the Obama administration in the US recently provided a direct $\$ 500$ million loan to two green-tech companies, Solyndra and Tesla Motors. While the latter is often glorified as a success story, the former failed miserably and became the latest example, used widely by both economists and the more popular treatment in the media, of government being unable to 'pick winners'. Indeed, the taxpayer picked up the bill (WOOD, 2012), and complained. This highlights the need to build a theoretical 
framework that can help the public sector understand (a) its 'portfolio' choices (RODRIK, 2013) and (b) how to socialise not only the risks of those investments but also the rewards. Is it right that the tax payer shouldered the Solyndra loss, yet made nothing from the Tesla profits?

\section{Figure 1: Early-stage and seed funding awards, SBIR and venture capital}

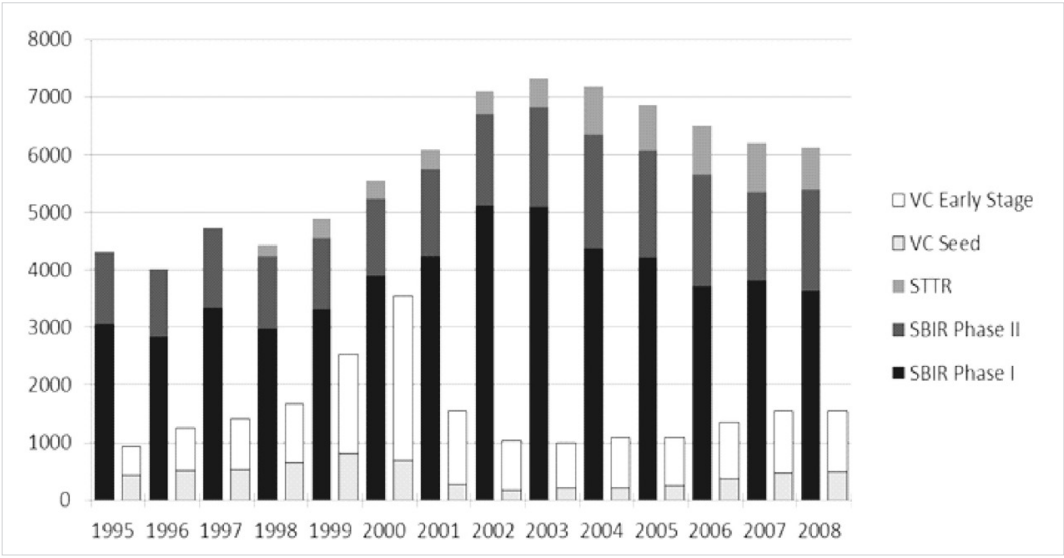

Source: Adapted from Block and Keller (2012).

The question comes down to whether in a market failure framework, the government deserves to retain a direct share of the profits generated from the growth that it fosters. Or put another way, are taxes currently bringing back enough return to government budgets to fund high-risk investments that will probably fail? It is well known that companies that benefit greatly from government investments have been successful in avoiding tax: Google, whose algorithm was funded by the NSF, has been criticised for such avoidance, as have also Apple and Amazon and a host of 'new economy' companies. Even if they were not dodging tax, tax rates, such as that on capital gains, have been falling due to the narrative that it is a narrow set of agents who are the real innovators and risk takers (LAZONICK; MAZZUCATO, 2013²).

\section{Socialising both risks and rewards}

This is because innovation is a highly uncertain process; it takes a very long time to develop new technologies, and the effort often ends up in a dry hole. For every Tesla (companies that receive public funding, and become market darlings), there

\footnotetext{
2 It was the National Venture Capital Association that in the late 1970s lobbied for capital gains tax to fall from $39.6 \%$ to $20 \%$ in 5 years (LAZONICK; MAZZUCATO, 2013). Warren Buffett has admitted that such tax changes did not affect investment, only inequality.
} 
are many Solyndras (companies that receive public funding, and then go bankrupt). For every Internet (technologies funded by government with great success) there are many Concordes (projects funded by government that fail commercially). Indeed Solyndra's recent bankruptcy has been used to talk about government failure, not recognising that if government is to act like a venture capitalist, which it historically has, it will-like all VCs have to-undergo many failures to reach some successes. However, what has not been thought through enough is the way in which to measure success/failure from a government's standpoint, and also how to makes sure that, like private VC funds, the state can reap back some return from the successes, in order to cover its losses, and the next round of investments: a revolving fund. This is especially important given the path-dependent and cumulative feature of innovation. Returns arise slowly, negative in the beginning, and slowly building up-potentially to a big pot (eg at the end of the biotech, dotcom and nanotech revolutions). One can think of returns as a cumulative distribution curve, with a slow rise at first, then with a steep increase, followed by levelling off. Unless we understand the collective process of innovation, we risk allowing a narrow group of actors to reap not just the returns proportional to their marginal contributions, but close to the entire integral under the curve.

So who gets what? Economists argue that the state already earns back a return for its investments, indirectly via the taxation system. There are four arguments against this reasoning: (1) tax evasion (legal and illegal) is common and realistically will not disappear; (2) taxes, such as capital gains, have been falling over the last decades, precisely through a false narrative about who the wealth creators are; (3) global movements of capital mean that the particular country or region (e.g. the European Union) funding the innovation might not reap the benefits in terms of local job creation; and (4) while it is of course right to think that investments in the 'basics', such as education, health and research, should not be thought about as earning a return, it is these directed investments at companies and particular technologies that pose a very different problem. If the state is being asked to make such investments (which it undoubtedly has been making and increasingly so, as financial markets have become even more speculative and short-termist), it is necessary for it to cover its inevitable losses when those arise.

Where technological breakthroughs have occurred as a result of targeted state interventions for specific companies, there is potential for the state to reap some of the financial rewards over time, by retaining ownership of a small proportion of the intellectual property created. This is not to say the state should ever have exclusive license or hold a large enough proportion of the value of an innovation to deter 
a wider spread of its application (and this has never been the case)-the role of government is not to run commercial enterprises, but to spark innovation elsewhere. However, a government should explore whether it is possible to own some of the value it has created, which over time could generate significantly higher value and then be reinvested into growth-generating investments. By adopting 'portfolio' approach to public investments in innovation, success from a few projects can then help cover the losses from many projects.

There are various ways to consider a direct return to the state for its investments in innovation. One is to make sure that loans and guarantees that are handed out by the state to business do not come without strings attached. Loans and grants could have conditions, such as 'income-contingent loans', similar to that of student loans. If a company receives a loan/grant from the state, it should be required to pay back a portion if and when it makes profits above a certain threshold (MAZZUCATO, 2013). This is not a complicated concept, of course, but it does run counter to some deepseated assumptions. Currently, with budget deficits under so much pressure, it is no longer possible to ignore the issue.

Apart from income-contingent loans, there is the possibility of the state retaining equity in the companies that it supports. Indeed, this does occur in some countries, such as Israel (through the Yozma public venture capital fund) or in Finland (where SITRA, one of Finland's public funding agencies, retained equity in its early-stage investments in Nokia). To be sure, equity stakes are also retained by state investment banks, such as BNDES (through BNDESPar, or 'BNDES Participations'), China Development Bank and $\mathrm{KfW}$, which are two lead investors in the emerging green economy (Mazzucato; PENNA, 2014). However, state equity in private companies is often feared in countries like the USA and the UK (and other countries that have copied the Anglo-Saxon model) for fear that the next step is 'communism'! Despite this fear, the most successful capitalist economies have had active states, making the risky investments that resulted in truly technological revolutions (PEREZ, 2002). We have been too quick to criticise public investments when things go wrong (for example, Concorde or Solyndra) and too slow to reward them when things go right (such as the Internet or Tesla).

\section{Conclusion: a new framework requires new questions}

The solutions derived from Market failure theory (downsizing the state apparatus, promoting market-based mechanisms to counter market failures, insulating public agencies from the private sector, etc.) might hold for steady state situations, but not for the situations in which public policy is required for transformation, such 
as those witnessed through the technological and socio-economic missions of the past. Such missions required an emphasis not on fixing market failures or minimising government failures but on maximising the transformative impact of policy that can shape and create markets.

Considering the need for government policy to 'transform', be catalytic, create and shape markets not just fix them, helps reframe the key questions of economic policy from static ones that worry about crowding out and picking winners to more dynamic ones that are constructive in forming the types of public-private interactions that can create new innovation and industrial landscapes. In this perspective, it is key for government to not just pick different technologies or sectors but ask what it wants from those sectors. In the same way that putting a man on the moon required many sectors to interact, the 'green' direction being debated today also requires all sectors to change. Green is not only about wind, solar and biofuels but also about new engines, new maintenance systems, new ways of thinking about product obsolescence (MAzzUCATO; PEREZ, 2014). This is not about prescribing specific technologies, but providing directions of change which bottom up solutions can then experiment around. As Stirling (2014) has recently put it:

The more demanding the innovation challenges like poverty, ill health or environmental damage, the greater becomes the importance of effective policy. This is not a question of "picking winners" - an uncertainty-shrouded dilemma which is anyhow equally shared between public, private and third sectors. Instead, it is about engaging widely across society, in order to build the most fruitful conditions for deciding what "winning" even means (STIRLING, 2014).

Government would benefit from adopting a portfolio approach to public investments in innovations, nurturing the explorative, plural, and trial and error aspect of change. This requires thinking not only about technological change in a new way but also organizational change.

Building the public agencies of the future with creative, adaptive and explorative capacity.

In sum, to approach the innovation challenge of the future, we must open up the discussion, away from the worry about 'picking winners' and 'crowding out' towards four key questions for the future should be:

1. Directions. How can public policy be understood in terms of setting the direction and route of change; that is, shaping and creating markets rather than just fixing them? What can be learned from the ways in which directions were set in the past, and how can we stimulate more democratic debate about such directionality? 
2. Evaluation. How can an alternative conceptualisation of the role of the public sector in the economy (alternative to Market failure theory) translate into new indicators and assessment tools for evaluating public policies, beyond the micro-economic cost/benefit analysis? How does this alter the crowding in/out narrative?

3. Organisational change. How should public organisations be structured so they accommodate the risk-taking and explorative capacity, and the capabilities needed to envision and manage contemporary challenges?

4. Risks and Rewards. How can this alternative conceptualisation be put into practice so that it frames investment tools so that they not only socialise risk but also have potential to socialise the rewards that enable 'smart growth' to also be 'inclusive growth'?

\section{References}

ABRAHAM, J. Pharmaceuticalization of society in context: theoretical, empirical and health dimensions. Sociology, 44(4), p. 603-622, 2010.

ANGelL, M. The Truth about the Drug Companies. New York: Random House, 2004. ARRow, K. An extension of the basic theorems of classical welfare economics. Paper presented at the Second Berkeley Symposium on Mathematical Statistics and Probability, Berkeley, 1951.

BLOCK, F.; KELLER, M. State of innovation: the U.S. government's role in technology development. Boulder: Paradigm, 2011.

KELLER, M. R.; BLOCK, F. Explaining the transformation in the US innovation system: the impact of a small government program. Socio-Economic Review, mws021, 2012.

BUCHANAN, J. Public choice: the origins and development of a research program. Champions of Freedom, 31, 2003.

Buck, T. Brain drain in Spain leaves scientific research on the wane. Financial Times, June 13, 2013. Available at http://www.ft.com/intl/cms/s/0/adb56dfe-d40e-11e28639-00144feab7de.html (accessed 2/7/2014).

BUfFETT, W. Stop Coddling the Super-Rich. 2011. Available at http://www.nytimes. com/2011/08/15/opinion/stop-coddling-the-super-rich.html?_r=0 (accessed 14/7/2014).

Climate Policy INITIATIVE. 'The Global Landscape of Climate Finance 2013'. CPI Report, October, 2013. Available at http://climatepolicyinitiative.org/wp-content/ uploads/2013/10/The-Global-Landscape-of-Climate-Finance-2013.pdf (accessed $1 / 6 / 2014)$.

Cohen, W.M.; LeVINTHAL, D.A. Absorptive capacity: a new perspective on learning and innovation. Administrative Science Quarterly, 35(1), 1990.

Dosı, G. Technological paradigms and technological trajectories: a suggested interpretation of the determinants and directions of technical change. Research Policy, 11(3), p. 147-162, 1982. 
EUROPEAN COMMISSION. Europe 2020: A European strategy for smart, sustainable and inclusive growth'. 2010. Available at http://ec.europa.eu/eu2020/pdf/COMPLET\%20 EN\%20BARROSO\%20\%20\%20007\%20-\%20Europe\%202020\%20-\%20EN\%20version. pdf (accessed 16/7/2014).

EUROWEEK. KfW domination of ECP ends fears of SSA crowding-out. EuroWeek, March 11, 2011. Available online at: http://www.globalcapital.com/article/k4qz6z833bhv/ kfw-domination-of-ecp-ends-fears-of-ssa-crowding-out (accessed 2/7/2014).

FAlCK, O.; Gollier, C.; WoessmanN, L. Arguments for and against Policies to Promote National Champions. In Falck, O; Gollier, C.; Woessmann. L. (Eds.). Industrial Policy for National Champions (p. 3-9). Cambridge, MA: MIT Press, 2011.

FMER (Federal Ministry of Education and Research). Education and Research in Figures 2013'. 2013. Available at http://www.bmbf.de/pub/education_and_ research_in_figures_2013.pdf (accessed 16/7/2014).

ForaY, D.; MOWERY, D.; NeLSON, R.R. Public R\&D and social challenges: What lessons from mission R\&D programs? Research Policy, 41(10), p. 1697-1902, 2012.

Fried, L., Shukla S.; SAWYER S., (Eds.). Global Wind Report: Annual Market Update 2011. Global Wind Energy Council, March, 2012. Available at http://gwec. net/wpcontent/uploads/2012/06/Annual_report_2011_lowres.pdf (accessed 24/1/2013).

FrIEDMAN, B.M. Crowding out or crowding in? The economic consequences of financing government deficits'. Brookings Papers on Economic Activity, 3, p. 593-654, 1979.

HANSON, J.A. Public Sector Banks and their Transformation. 6th Annual Financial Markets and Development Conference: The Role of State-Owned Financial Institutions - Policy and Practice. Washington, D.C.: The Brookings Institution, 2004. HIRSCHMAN, A.O. Development Projects Observed: Brookings Institution Press, 1967. JUDT, T. Ill Fares the Land. New York: Penguin Press, 2011.

KAKABAdSE, A.; KAKABADSE, N. Trends in Outsourcing:: Contrasting USA and Europe. European Management Journal, 20(2), p. 189-198, 2002.

KEYNES, J.M. The end of laissez-faire. London: Prometheus Books, 1926.

General Theory of Employment, Interest and Money: Atlantic, 2006

(1936).

KRUEGER, A.O. The political economy of the rent-seeking society. The American Economic Review, 64(3), p. 291-303, 1974.

LAMONICA, M. R\&D faces its own fiscal cliff. MIT Technology Review, February 28, 2013. Available at http://www.technologyreview.com/news/511886/rd-faces-itsown-fiscal-cliff/ (accessed 2/7/14).

LAZONICK, W.; MazzUCATO, M. The Risk-Reward Nexus in the Innovation-Inequality Relationship: Who Takes the Risks? Who Gets the Rewards?' Industrial and Corporate Change, 22(4), p. 1093-1128, 2013.

LISBOA, M.B.; LATIF, Z.A. Democracy and Growth in Brazil. Insper Working Paper, 311/2013. 2013.

Mazzucato, M. The Entrepreneurial State: Debunking the Public vs. Private Myth in Risk and Innovation. London: Anthem, 2013. 
Financing innovation: Creative destruction vs. destructive creation. Industrial and Corporate Change, 22(4), p. 851-867, 2013b.

MAZzUCATO, M. Costruire lo Stato innovatore: un nuovo quadro per la previsione e la valutazione di politiche economiche che creano (non solo aggiustano) il mercato. In: Special Issue The Entrepreneurial State: A Discussion (Lo Stato innovatore: una discussione), Economia \& Lavoro, 3:(Sept-Dec), 2014.

MAZZUCATO, M.; PENNA, C. Beyond market failures: the market creating and shaping role of state investment banks. University of Sussex SPRU working paper SWPS 2014-1, 2014. https://www.sussex.ac.uk/webteam/gateway/file.php?name=201421-swps-mazzucato-and-penna.pdf\&site $=25$

Mazzucato, M.; Perez, C. Innovation as Growth Policy . In: Fagerberg, J; Laestadius, S; Martin, B. (Eds.). The Triple Challenge: Europe in a New Age. Oxford University Press: Oxford, forthcoming, 2014.

MowerY, D. C. Military R\&D and innovation. In: Hall, B. H.; Rosenberg, N. (Eds.). Handbook of the Economics of Innovation (Vol. 2, pp. 1219-1256). 2010.

National ReSEARCH Council. Energy Research at DOE: Was It Worth It? Energy Efficiency and Fossil Energy Research 1978 to 2000, Committee on Benefits of DOE R\&D on Energy Efficiency and Fossil Energy, Board on Energy and Environmental Systems, Division on Engineering and Physical Sciences. 2001. Available at http:// www.nap.edu/catalog.php?record_id=10165 (accessed 22/4/2014).

NELSON, R.R.; WINTER, S.G. An Evolutionary Theory of Economic Change. Cambridge (MA): Belknap Press, 1982.

PEREZ, C. Technological revolutions and financial capital: the dynamics of bubbles and golden ages. Cheltenham, UK: Edgar Elgar, 2002.

POLANYI, K. The great transformation: the political and economic origins of our time. Boston: Beacon Press, 2001 (1944)..

RODRIK, D. Green Industrial Policy: Princeton University Working Paper, 2013.

SCHOT, J.; GeELS, F. Typology of Sociotechnical Transition Pathways. Research Policy, 36 (3), p. 399-417, 2007.

Shellenberger, M.; Nordhaus, T.; Jenkins, J.; Trembath, A. US Government Role in Shale Gas Fracking History: An Overview and Response to Our Critics. The Breakthrough, March 2, 2012. Available at http://thebreakthrough.org/archive/ shale_gas_fracking_history_and (accessed 13/7/2014).

StIGLITZ, J.; WEISS, A. Credit rationing in markets with imperfect information. American Economic Review, 3(71), p. 393-410, 1981.

STIRLING, A. Direction, Distribution and Diversity! Pluralising Progress in Innovation, Sustainability and Development. STEPS Working Paper: Vol. 32, 2009.

STIRLING, A. Making choices in the face of uncertainty. Themed Annual Report of the Government Chief Scientific Adviser, Chapter 2 (June), 2014. Draft mimeo.

THE ECONOMIST. Picking winners, saving losers: the global revival of industrial policy. The Economist, 2010. Available online at: http://www.economist.com/node/16741043 (accessed 1/6/2014).

TULLOCK, G.; SELDON, A.; BRADY, G.L. Government failure: a primer in public choice. Washington, DC: Cato Institute, 2002. 
WEIR, N. Government R\&D hit by disproportionate cuts, again. Campaign for Science and Engineering (CaSE), January 27, 2014. Available at http://sciencecampaign.org. $u k / ? p=13593$ (accessed 23/5/2014).

WEISS, L. America Inc: Innovation and Enterprise in the National Security State. Cornell University Press, NY, 2014.

WoLf, C. Markets or governments: choosing between imperfect alternatives. Cambridge, Mass.: MIT Press, 1988.

WooD, R. Fallen Solyndra Won Bankruptcy Battle but Faces Tax War. Forbes, 11 June, 2012. Available at http://www.forbes.com/sites/robertwood/2012/11/06/ fallen-solyndra-won-bankruptcy-battle-but-faces-tax-war/ (accessed 29/1/2014).

Mariana Mazzucato, R.M.

Phillips Professor in the Economics of Innovation, SPRU University of Sussex. Contato: m.mazzucato@sussex.ac.uk. 